\section{Understanding Art-Making as Documentation}

Tim Gorichanaz

Department of Information Science

College of Computing \& Informatics

Drexel University

This is a pre-publication version of a paper in the Fall 2017 issue of Art Documentation: Journal of the Art Libraries Society of North America. The authoritative, published version of this paper differs from this version; please refer to and cite the published version.

\section{Introduction}

Arts information professionals are typically concerned with the documentation of artwork. As a provocation, in this paper I explore how works of art might be considered documents on their own. This notion has a number of implications.

I begin with a discussion of art documentation in general, which is then contextualized in the historical trajectory of documentation studies. As we will see, this trajectory is characterized by three epistemic phases, evolving from logical positivism to broad semiotics. It is within the last of these phases that considering art as document is the most useful. Next, I discuss a few scholarly works, chiefly from France, that have begun to problematize the traditional relationship between art and document; in the context of the epistemological history of the document, it becomes clear how this work can be extended and how all art can be considered documentary. I then discuss three implications of art being documentary: Art references something outside itself; artworks are part of broader systems; and art can reveal something about how it references. If artworks are documents, then art-making is a process of documentation. Thus, in the final section of the paper, I discuss the relationship of a general model for documentation to the work of artists, which points to a number of areas for further research within this framework.

By putting art-making in the terms of information science, this paper seeks to foster counderstandings between artists and information scientists. Moreover, whereas research on artists' information behavior (not to mention information behavior in general) has for the most 
part been limited to information needs and seeking, there is room and a need for research across the span of the "information chain" of artwork. ${ }^{1}$ Doing so offers a unifying framework for studying the information behavior of artists and draws connections between theory in information science and the pragmatics of art librarianship.

\section{Art Documentation in Its Essence}

Generally speaking, art documentation involves the creation and organization of documents representing and related to artworks and artists. That is a practical definition, but what is art documentation in its essence? To address that question, it is necessary to probe what is meant by "document."

In art documentation, as in modern society at large, a document is typically considered to be evidence in support of a fact. In art documentation, that "fact" is generally a given artwork or an aspect of an artist's life. Examples include photographs of works, contracts and correspondence. The relationship between documents and facts is generally taken for granted, but it is actually an ideological position. The ontological and epistemological layers of that position have been the subject of some scholarly discussion over the past century, but particularly since the 1990s, in (neo-)documentation studies. ${ }^{2}$

Though the concept of the document stretches back to Antiquity, the document was first theorized by the Belgian lawyer and bibliographer Paul Otlet at the turn of the 20th century. ${ }^{3}$ For Otlet, the paragon document was the book, but his work led to the important contribution that things besides books could serve as documents-newspapers, maps and sculptures, for instance. Otlet understood the document as, essentially, a representation of the world composed of facts. However, Otlet found documents to be inefficient-books, for instance, were verbose, repetitive and difficult to search. ${ }^{4}$ To overcome this, Otlet sought to develop methods to extract the facts of a document and store them in a centralized database for later retrieval. His prime vision was the Mundaneum, a universal database of all knowledge, which in some ways is a theoretical precursor to the internet. Most germane to my discussion here, Otlet assumed the documentation 5 process to be objective and self-evident-to put it a bit uncharitably, just a matter of tallying facts. This seems to be a logical positivist position (the paradigm du jour in

\footnotetext{
${ }^{1}$ Lyn Robinson, "Information Science: Communication Chain and Domain Analysis," Journal of Documentation 65, no. 4 (2009): 578-591.
}

2 Documentation studies was an earlier name for what is now better known as information science or studies, at least the Anglophone world. Especially since the 1990s, some scholars have been arguing that the concept of the document is preferable to information for a number of reasons. This return to documentation studies is sometimes termed neo-documentation studies. This will not be discussed in detail here, but see: Roswitha Skare, Niels Windfeld Lund, and Andreas Vårheim (Eds.), A Document (Re)turn: Contributions from a Research Field in Transition (Frankfurt: Peter Lang, 2007).

${ }^{3}$ Niels Windfeld Lund, "Document Theory." Annual Review of Information Science and Technology 43, no. 1 (2009): 399-432.

${ }^{4}$ Paul Otlet, Traité de documentation: Le livre sur le livre: Théorie et pratique (Brussels: Editions Mundaneum, Palais Mondial, 1934). Though this work has never been translated into English, selections from it (as well as other works) are available in: Paul Otlet, International Organisation and Communication of Knowledge: Selected Essays of Paul Otlet, trans. W. Boyd Rayward (Amsterdam: Elsevier, 1990).

${ }^{5}$ N.B.: Documentation refers to document creation. 
many fields at the time), as it considers meaningful only that which is externally observable and formulable into words.

In the mid-20th century, Otlet's view was challenged by Suzanne Briet, ${ }^{6}$ a French librarian. Whereas for Otlet the document was defined by factual representation, for Briet it was defined by indexicality. Indexicality, or the indexical mode of reference, is a concept from Charles Peirce's theory of semiotics, referring to a relationship between two entities that can be exemplified by pointing. ${ }^{7}$ In Briet's view, documents were not necessarily objective proof of external things, but associations. In shifting the definition in this way, Briet suggested that documentation was not a straightforward, self-evident matter-and indeed that understanding the documentation process is essential to understanding any given document.

Also important to Briet's conceptualization of the document was its capacity for secondary documents to be derived from any given primary document:

For example, an antelope of a new kind has been encountered in Africa by an explorer who has succeeded in capturing an individual that is then brought back to Europe for our Botanical Garden. A press release makes the event known by newspaper, by radio, and by newsreels. The discovery becomes the topic of an announcement at the Academy of Sciences. A professor of the Museum discusses it in his courses. The living animal is placed in a cage and cataloged (zoological garden). Once it is dead, it will be stuffed and preserved (in the Museum). It is loaned to an Exposition. It is played on a soundtrack at the cinema. Its voice is recorded on a disk. ... The cataloged antelope is an initial document and the other documents are secondary or derived. 8

In a word, Briet demonstrated that context was central to the document's being and meaning. Such a view is also reflected in the changing nature of the scientific enterprise in general. Otlet's Mundaneum reflected the assumptions of science in his age, but dissent came about soon enough: Ludwig Fleck ${ }^{9}$ denied the possibility of individual fact retrieval, arguing that a so-called fact was meaningless unless one considered the context from which it arose. This view was further developed and later popularized by Latour and Woolgar, 10 who traced the subtle slippages that transform context-bound, limited observations into the broader "facts" of science. Moreover, a document-aware reading of Latour and Woolgar would conclude that, in large part, the enterprise of science is really a matter of deriving documents, to use Briet's term.

Though the difference between Otlet's and Briet's conceptualization of the document may seem subtle, it has real consequences. For Otlet, an artwork and its photograph were equivalent, as they both presented the same facts. Not so for Briet, who would see them only as related. And whereas Otlet's framework could not account for, say, a menu serving as a document of a performance meal-as-art, for Briet such a menu is perfectly documentary.

${ }^{6}$ Suzanne Briet, What Is Documentation?, trans. Ronald E. Day, Laurent Martinet, and Hermina G. B. Anghelescu (Langham, MD: Scarecrow Press, 2006), 9-46.

7 Daniel Chandler, Semiotics: The Basics (2nd ed.) (New York: Routledge, 2007).

${ }^{8}$ Briet, $10-11$

${ }^{9}$ Ludwig Fleck, Genesis and Development of a Scientific Fact (Chicago: University of Chicago Press, 1979).

${ }^{10}$ Bruno Latour and Steve Woolgar, Laboratory Life: The Social Construction of Scientific Facts (Princeton, NJ: Princeton University Press, 1986). 
Briet's work has been taken further by contemporary scholars in the neo-documentation tradition, which began in Norway in the mid-1990s.11 Prominent among these scholars is Michael Buckland, whose landmark 1997 paper "What is a 'document'?" brought the work of Otlet and Briet to a wider (English-speaking) audience.12 Taking Briet's work further, Buckland began developing a conceptualization of the document as anything that involves meaning, material and culture. 13 More recently, Buckland has argued that the status of being a document is attributive (by individuals or social groups) and that every document has cultural, media type and physical aspects, such that spoken language, music and live performances can also be considered as documents in themselves. 14 Indeed, anything can be considered a document from the semiotic perspective, even if it was not expressly produced to be a document: According to Buckland's most recent typology, documents can be created as documents by the maker (e.g., a legal contract), considered as documents by groups (e.g., the Liberty Bell), or made into documents by individual beholders (e.g., an unassuming object of personal significance). .15

We can summarize the contemporary view in saying that something is a document if it moves someone toward an understanding of something else. In this sense, the document is defined by its use. Critically, a document need not be a factual representation of something else to be a document. Indeed, this scholarship has challenged the seemingly stable objectivity of the notion of "fact" in showing the levels of interpretation that go into creating or deriving any document.16 With this view, one might ask the question: Can art, too, be considered a document? And more importantly: What value might such a perspective offer?

\section{Problematizing the Art/Document Divide}

Traditionally speaking, art documentation has held the work of art on one hand, and the documents representing that work on the other. Challenging this dichotomy, two scholars have begun to discuss how artwork itself can be documentary. Philip Auslander, for one, problematizes the documentation of performance art by discussing what he calls "theatrical documentation":

In the theatrical category, I would place a host of art works of the kind sometimes called "performed photography," ranging from Marcel Duchamp's photos of himself as Rrose

11 Skare, Lund, and Vårheim, A Document (Re)turn.

12 Michael K. Buckland, "What is a 'Document'?," Journal of the American Society for Information Science 48, no. 9 (1997): 804-809.

${ }^{13}$ Michael K. Buckland, "Northern Light: Fresh Insights into Enduring Concerns," in A Document (Re)turn: Contributions from a Research Field in Transition, ed. Roswitha Skare, Niels Windfeld Lund, and Andreas Vårheim (Frankfurt, Germany: Peter Lang, 2007), 316-322.

${ }^{14}$ Michael K. Buckland, "Document Theory: An Introduction," in Records, Archives and Memory: Selected Papers from the Conference and School on Records, Archives and Memory Studies, University of Zadar, Croatia, May 2013, ed. Mirna Willer, Anne J. Gilliland, and Marijana Tomić (Zadar, Croatia: University of Zadar, 2015), 223-239.

15 lbid.

${ }^{16}$ For an account explicitly linking the scientific enterprise to documents in the neo-documentation tradition, see: Bernd Frohmann, Deflating Information: From Science Studies to Documentation (Toronto: University of Toronto Press, 2004). 
Selavy to Cindy Sherman's photographs of herself in various guises ... These are cases in which performances were staged solely to be photographed or filmed and had no meaningful prior existence as autonomous events presented to audiences. 17

Auslander goes on to draw an account of how performance art and its documentation coconstitute each other. Auslander seems chiefly interested in drawing an account of performance art documentation, but his work exposes something deeper: Whereas documents of performance art are traditionally or naively understood as proof of the performance that transpired, these theatrical documents firmly assert themselves as works of art in themselves.

Next, Anne Bénichou discusses some examples of contemporary plastic art that blur the boundary between art and document.18 For instance, the "test pieces" by Eva Hesse were originally made as sculptural sketches or experiments; as such, they serve as documents for finished pieces (e.g., providing a model for preservation and restoration). But some of these test pieces approach "finished" status, and moreover many of them are now exhibited on their own as artworks in themselves.

Auslander and Bénichou offer some examples wherein art-making is documentation, but they stop short of arguing that all art-making is essentially a kind of documentation. This may be because they seem to conceptualize the document in an Otletian way. In the case of Auslander, the primary artwork may not actually exist, and in the case of Bénichou, the work and document may be one and the same; even so, they conceptualize the document as a means of transmitting facts, directly representative of a work of art.

These views can be advanced by incorporating the neo-documentation perspective of the document as semiotic. As an example of this, museologist Kiersten Latham sketches such an account in her framework for considering museum objects as documents, drawing on Briet and Buckland: Museum objects are material, collected, deemed meaningful and wrapped up in cataloging and other processes.19 Even accepting Latham's argument, it could be argued that would-be museum objects are no longer documents outside the museum setting, and so some further consideration may be necessary to secure the view that any artwork can be a document.

However, given Buckland's more recent conceptualizations of the document, 20 it is clear that the status of being a document is attributable even outside any particular institution; moreover, any given document may provide evidence of any number of things. As such, I contend that all art can be considered a document, and all art-making documentation. On the surface, of course, a work of art is a document as evidence of the artist's work-but that is somewhat circular. More deeply, we can see that artistic works perform documentary reference in interesting ways: They may reference not observable facts of the world, but deeply felt meanings, states of mind and the like. For example, if we consider the theatrical documents discussed by Auslander to be artistic works in themselves, what they document is that the trust we place in documents may be exploited.

In the following section, I will discuss the implications of seeing artwork as documentary.

\footnotetext{
${ }^{17}$ Philip Auslander, "The Performativity of Performance Documentation," PAJ 84 (2006): 1-10.

${ }^{18}$ Anne Bénichou (Ed.), Ouvrir le document: Enjeux et pratiques de la documentation dans les arts visuals contemporains (Dijon, France: Les Presses du Réel, 2010), 47-76.

19 Kiersten F. Latham, "Museum Object as Document," Journal of Documentation 68, no. 1 (2012): 45-71.

${ }^{20}$ Buckland, "Document Theory: An Introduction."
} 


\section{Understanding Art as Document}

Fundamentally, every document is something that references something outside itself and is part of a broader system. Moreover, when analyzed critically, a document also discloses how it references. If we consider art as a document, light is shed on all these conceptual aspects of art. In the following sections, each of these will be discussed in turn.

\section{Artwork references something outside itself}

Artworks, of course, exist on their own and assert their own existence. However, they also point to things outside themselves. This has been asserted with respect to contemporary conceptual art, such as that by Marcel Duchamp,21 but in my view it is the case for all art. To understand this more deeply, we can consider the work of philosopher Nelson Goodman. Of course, Goodman is only one commentator among many in this realm. I have selected Goodman's work for exposition here because he ambitiously attempted to bridge formal analytic philosophy with the ineffability of art, rather than dismissing one or the other. Moreover, Goodman describes the artist's work as a form of classification, immediately suggesting synergy with the information professions. His work, now 40 years old, has seen some comment within art history and theory, but in my view it also has important relevance for information studies, and this is why I focus on it here. Further research may find worth in exploring the question of the document through other theoretical frames.

In Languages of Art,22 Goodman presents the general view that humans use symbols in perceiving, understanding and constructing the worlds of our experience. As part of this, artworks do not merely reflect the world, but they help create new ones. Goodman suggests that humans have faculties for understanding artworks just as for natural language (indeed, the same underlying faculties), and these faculties involve a referential system. Throughout the book, Goodman develops a theory of how this system may work. While Goodman's argument is rooted in analytic philosophy, which is sometimes associated with logical positivism, Goodman's work seeks to transcend the major current of analytic philosophy by honoring non-linguistic symbolic systems. Goodman's work is richly textured, and is worthy of lengthy scrutiny; here, however, I will only discuss a few of Goodman's concepts, as relevant to the discussion at hand.

In one section of the book, Goodman argues that art is a kind of representation, but not one that hinges on resemblance (which would be the naive assumption). After all, an oil painting of a buffalo is a smallish, rectangular and flat assemblage of cloth and oil which resembles very little a living, hulking buffalo. Thus, rather than resemblance, art is representation in the sense of reference, or something standing for something else-what others have called indexation. 23 "This is not a matter of copying but conveying. It is more a matter of 'catching a likeness' than duplicating."24

\footnotetext{
${ }^{21}$ Rosalind Krauss, "Notes on the Index: Seventies Art in America," October 3 (Spring 1977): 68-81.

22 Nelson Goodman, Languages of Art (2nd ed.) (Indianapolis, IN: Hackett, 1976).

${ }^{23}$ Cf. Chandler, Semiotics: The Basics, and Briet, What is Documentation?

${ }^{24}$ Goodman, Languages of Art, 14.
} 
Figure 1. An artwork referencing through denotation and exemplification, according to Goodman's framework. The image of George Washington is reproduced from a painting by Gilbert Stuart, held at the Clark Art Institute.
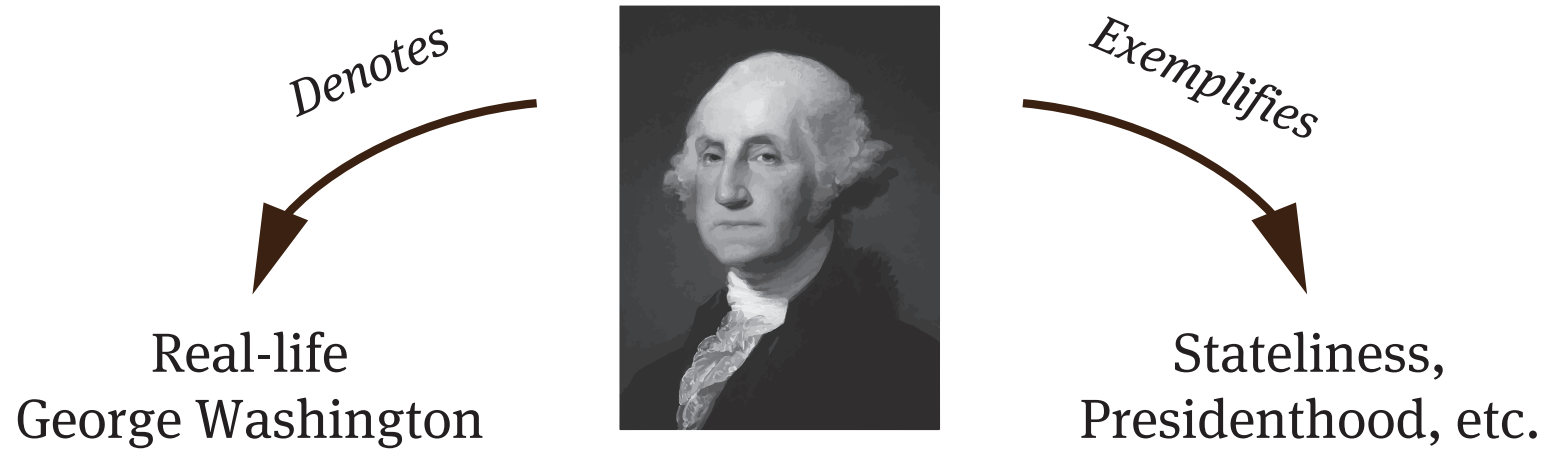

Art references in two key ways, according to Goodman (see Figure 1). First, art can denote. In denotation, a work of art functions as a label for its subject. In this case, the reference is rather straightforward. Second, art can exemplify. In exemplification, a work of art refers to a label. It does this by being a sample of or embodying some particular aspects of that label. For instance, a green tailor's swatch exemplifies a particular color green and/or a particular fabric; however, the swatch does not exemplify size or shape. Exemplification can be not only literal, but also metaphorical. In the metaphorical case, Goodman terms it expression. With metaphor, "pictures express sounds or feelings rather than colors."25 For example, the Mona Lisa exemplifies intrigue through metaphor, and the Scream exemplifies anguish. This concept accounts for how abstract art, such as non-objective painting and instrumental music, can be meaningful even though they do not represent anything that can be described through propositional statements. With this framework to hand, it becomes obvious that image retrieval systems predominantly organize images according to their denotation, missing their exemplification entirely.

In both denotation and exemplification, artistic reference is a matter of abstraction-in the sense the word is used in information science, referring to a summary or distillation. As Goodman says, "To portray faithfully is to convey a person known and distilled from a variety of experiences." 26 Thus, to make art is to participate in a kind of classification: "The making of a picture commonly participates in making what is to be pictured. ... Representation and description thus involve and are often involved in organization." 27 Indeed, Goodman sees art as a means of organizing the world "to the extent that the artist or writer grasps fresh and significant relationships and devises means for making them manifest." 28 These observations suggest certain structural similarity between the work of artists and documenters, which will be taken up further on.

\footnotetext{
25 Ibid., 86.

26 Ibid., 20.

27 Ibid., 32.

28 Ibid., 32-33.
} 


\section{Artworks are part of broader systems}

Sociologist Howard Becker's ground-breaking book Art Worlds 29 challenged the romantic notion of the artist as an individual genius by demonstrating the complex network of people and materials-and rote labor-involved in every work of art. In this way, Becker flattens the ontology of the art world, giving visibility to the manufacturers, couriers, shop owners, gallery owners, critics, etc., who all give rise to a work of art, in addition to the credited artist.

French documentation scholar Gérard Régimbeau presents a framework based on Becker's work for considering the information behavior of artists. 30 This framework entails concentric circles of worlds, networks and apparatuses. Worlds include Becker's "art world" and other, overlapping sociological worlds. Networks entail tracing the processes and relationships that link the diverse entities of the worlds. Apparatuses refer to the physical, mediated activities involved in planning and making a work of art, such as using an information system to conduct research and putting brush to canvas. These concepts are meant to allow different levels of analysis and detail to be possible. As relevant to the discussion here, what they provide is a toolkit for thinking through the broad systems within which art works.

All in all, Régimbeau argues that a univocal analysis of art-making is necessarily insufficient; a scholar cannot simply consider particular masterpieces or mediums in isolation, but rather they must consider the complex network of interrelations that underpin the creation of any work of art. This position is also supported by the work of information scientist Tonyia Tidline, who conducted a narrative analysis of the information behavior of artists, 31 finding that engaging with other artwork is an important part of the creative process and artists' development.

\section{Artworks say something about how they reference}

Information science theorist Ron Day has long championed critical inquiry in information science, on the grounds that such inquiry can expose assumptions and other hidden layers of meaning. When a document is analyzed critically, Day argues, it reveals how it references, on top of simply what it references.32 For instance, it is clear that a document becomes a document once it is situated within a classificatory scheme or other broader system. The document's place within that system (e.g., the keywords used to represent it) shows what features of a thing are important or meaningful within that system. A similar view has been developed by Melanie Feinberg, who discusses how such features of information systems can be "read." 33

In the case of art, any given work is situated within systems of historical trajectory, local and global sociopolitical issues, and idiosyncratic associations. Examining a given work of art with these systems (e.g., how and where it is displayed or not, how it is discussed or not, etc.) in mind can show what is important to a culture, locality or individual. In the view of philosopher

\footnotetext{
29 Howard Becker, Art Worlds (Berkeley: University of California Press, 1982).

30 Gérard Régimbeau, "L'information et la documentation en art contemporain dans ses dispositifs: cadre théorique et études de cas," in Dispositifs info-communicationnels: Questions de médiations documentaires, ed. Viviane Couzinet (Paris: Lavoisier, 2009), 229-263.
}

31 Tonyia J. Tidline, "Making Sense of Art as Information" (PhD diss., University of Illinois UrbanaChampaign, 2003).

${ }^{32}$ Ronald E. Day, Indexing It All: The Subject in the Age of Documentation, Information, and Data (Cambridge, MA: The MIT Press, 2014).

${ }^{33}$ Melanie Feinberg, "Reading Databases: Slow Information Interactions Beyond the Retrieval Paradigm," Journal of Documentation 73, no. 2 (2017): 336-356. 
Martin Heidegger, the possibility of this analysis is the highest potential and true value of art. ${ }^{34}$ For Heidegger, art illuminates what people find worthwhile and true; consequently, it informs their understanding of the world and themselves. And not only does art illuminate the worthy and true, however; art constitutes it. However, Heidegger laments that too often today we are inclined to see works of art in hermetic isolation, and considered in this way art does not have a chance to work. That is, art only works when it is woven into the fabric of human life.

\section{Modeling Art-Making as Documentation}

As we can now see, framing artworks as documents reveals the structural similarity between the work of artists and information professionals. Both are concerned with the organization and articulation of aspects of reality, broadly construed. Herewith, information professionals, for their part, can better assist artists by considering art-making in comparison and contrast with their own practice. The above discussion was an inchoate attempt at sketching the key areas of this sort of consideration.

Moreover, examining the work of artists might lead to new insights for information science in general. For example, a closer look at how art references through its own mechanisms of classification and organization may offer guidance to information science in the areas of classifying and organizing nonverbal information, which is an area of growing importance in today's visually-oriented information climate. To extend this possibility, this section explores in more detail how the process of art-making can be conceptualized as documentation.

\section{Beyond information seeking}

David Bawden and Lyn Robinson suggest, in their textbook overview of information science, that the unique contribution of information science is that it conceptualizes along the entirety of the information-communication chain. 35 It is notable, then, that research in human information behavior has almost exclusively focused on information seeking, as has been remarked many times. 36

Research on the information behavior of artists is no exception. William Hemmig provides a review of this research, which allows him to draw several coherent conclusions about the information needs and seeking of artists, but nothing about their information use, sharing, creation, etc.37 Since Hemmig's 2008 review, there have been a handful of studies on artists' information behavior, but this limitation stands. Though scholars have pointed out the paucity of research on and difficulties surrounding recruiting practicing artists outside educational institutions, few seem to have been troubled by the lack of research on the information use of artists. (The work of Tidline, discussed above, is a notable exception, but it is also notable that this work only exists in the form of an unpublished dissertation.) This limitation is particularly crucial in light of the findings of an exploratory case study by Sandra Cowan, which suggest that

\footnotetext{
${ }^{34}$ Martin Heidegger, "The Origin of the Work of Art," in Poetry, Language, Thought, trans. Albert Hofstadter (New York, NY: Harper \& Row, 1971), 15-86.

35 David Bawden and Lyn Robinsin, Introduction to Information Science (Chicago: Neal-Schuman, 2012).

${ }^{36}$ Donald O. Case and Lisa G. Given, Looking for Information: A Survey of Research on Information Seeking, Needs and Behavior (4th ed.) (Bingley, UK: Emerald, 2016).

${ }^{37}$ William S. Hemmig, "The Information-Seeking Behavior of Visual Artists: A Literature Review," Journal of Documentation 64, no. 3 (2008): 343-362.
} 
artists may not view themselves as information needers and seekers, but rather as joyful, creative and engaged builders of understanding. 38

\section{Documentation as a framework for information creation and use}

If art can be considered a document, then art-making can be considered documentation. In this case, we can consider Niels Windfeld Lund's general model of documentation for some insight into the art-making process. ${ }^{39}$ At the very least, considering a model can point to where further empirical research is needed. 40 Lund conceptualizes documentation in this way: Documentation entails a producer, a set of instruments (including media) for producing, a mode of using these instruments, and the resulting document (see Figure 2). This process unfolds in time and is constrained and enabled by any number of factors, from socioeconomic pressures to individual whims. Some of these factors are "baked into" the finished document and are readily apparent upon inspection of the document, while others can only be discovered by looking at the documentation process.

Figure 2. The documentation process, adapted from Lund.

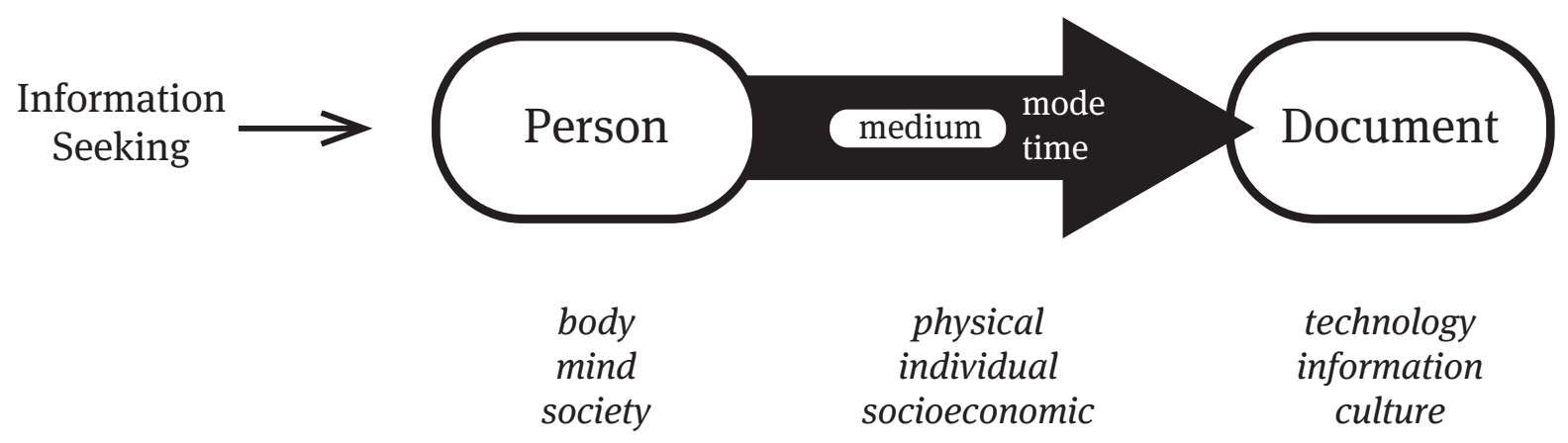

Each of these aspects and factors of the documentation process can be examined in three dimensions: the physical, the mental and the social. Lund insists these three analysis must be done separately, but other scholars have suggested that they may be done in symphony. ${ }^{41}$ As shown in Figure 2, the labels for these dimensions depend on the aspect of documentation in question (i.e., person, process, or product). For instance, body is the physical dimension of the

${ }^{38}$ Sandra Cowan, "Informing Visual Poetry: Information Needs and Sources," Art Documentation 23, no. 2 (2004): 14-20.

39 Niels Windfeld Lund, "Documentation in a Complementary Perspective," in Aware and Responsible: Papers of the Nordic-International Colloquium on Social and Cultural Awareness and Responsibility in Library, Information and Documentation Studies (SCAR-LID), ed. W. Boyd Rayward (Lanham, MD: Scarecrow Press, 2004), 93-102.

40 T. D. Wilson, "Information Behavior: An Interdisciplinary Perspective," Information Processing and Management 33, no. 4 (1997): 551-572.

${ }^{41}$ Roswitha Skare, "Complementarity - A Concept for Document Analysis?," Journal of Documentation 65, no. 5 (2009): 834-840. 
person, while technology is the physical aspect of the document. This is meant only as an attempt to locate these various concepts along the documentation process, with the understanding that in reality they cannot be so cleanly separated or aligned.

An example may be in order. Consider a painter who, after obtaining things like inspiration, materials and information on, say, the time of day and season when the setting looks a certain desirable way, stands on the bank of the Schuylkill River in Philadelphia to paint en plein air the Columbia Railroad Bridge. As a person, the painter can be described (in some detail, if a bit reductively) in terms of their physical body (e.g., height), their mind (intellectual interest in the scene) and their place in society (as an "artist," and thinking about the genre and style they are about to paint). The process of painting happens in time, through the medium of painting, with particular actions such as mixing and layering paints, and it too can be described in terms of the physical objects (paint, canvas, easel, brushes), the individual (idiosyncrasies) and the socioeconomic (costs, value creation). The finished painting, likewise, can be described in terms of its technology (paint, style), its information (what it expresses and represents) and culture (its place in the world of art).

This model of documentation, shows how different aspects of an artist's world are related and come to bear on the art-making process. For instance, an artist's training relates to the individual aspects of art-making, and their artistic groups and associations relate to the sociocultural aspects. It is the purview of information science to point out the synergy among these processes, thereby unifying them and helping the artistic enterprise to advance.

Considered as a tool for contextualizing and focusing research efforts, this model suggests that the mental/informational aspects of art-making may be the least understood; they would seem to relate to the outcomes of information seeking, among other things, which have been the least studied in information behavior generally. This is to say, Lund's framework offers a sociocognitive picture of what goes on in documentation, which is certainly relevant to artmaking and offers some future direction for research in artists' information behavior. However, as art-making is personally meaningful and often idiosyncratic, phenomenological (i.e., lived experience) color is needed in order to plumb the special role of human consciousness in artmaking.

To adumbrate a way forward, we can turn again to the work of Goodman. In the conclusion to Languages of Art, Goodman suggests that there are three intermingled purposes for making a work of art.42 First is the communication of ideas and feelings, as "discoveries become available knowledge only when preserved in accessible form";43 second is the building of skills, both in a technical sense and in the sense of "developing our abilities and techniques to cope with future contingencies" 44 through exercising one's symbolizing faculties; and third is the intrinsic purpose, wherein an artist works "just for the joy of it or because he cannot stop." 45 Centrally, for the artist:

The drive is curiosity and the aim enlightenment. Use of symbols beyond immediate need is for the sake of understanding, not practice; what compels is the urge to know, what delights

\footnotetext{
42 Goodman, Languages of Art.

43 Ibid., 260.

44 Ibid., 256.

45 Ibid., 257.
} 
is discovery, and communication is secondary to the apprehension and formulation of what is to be communicated. 46

This view shows how the physical, mental and social may be intertwined in the work of the individual artist-as-documenter. The physical corresponds to the building of skills, the mental corresponds to the joy of art-making, and the social corresponds to the communication of ideas. Moreover, we can see that the endeavor of art-making spills out of itself: The artist's skillbuilding and drive for enlightenment, Goodman points out, relate not only to art-making but to living life in general.

Again, on Bawden and Robinson's view of the field, it is the purview of information science to point out the synergy and interrelations of the different actors, institutions and fields of study concerned with art so that, as a whole, we may advance. Moreover, bringing all these processes under the same umbrella helps show which aspects may be under-theorized and underdeveloped. It also helps everyone involved understand, by virtue of context, others' contributions.

\section{Conclusion}

In this paper, we have considered how a work of art can be not only documented, but also a document. By describing art-making in the terms of information science, as documenting, this paper has sought ground for deeper co-understandings between artists and information professionals. This discussion has provided a framework for thinking of the artist's work in a multidimensional way, while simultaneously challenging the predominant popular view of what a document can be.

As mentioned above, further research could explore these ideas through other theoretical orientations. In addition to philosophical approaches to art besides Goodman's, alternative concepts to the document could be explored; concepts such as artifact, object and record all have too-often-separate worlds of discourse that may benefit from mutual discussion.

In closing, I reiterate that this paper has invited not only the consideration of art-making as documentation, but the consideration of documentation itself as a kind of art-making. Goodman suggested that art-making is driven by the virtues of communication, skill-building and intrinsic purpose. Clearly, the work of documentation in the information professions is geared toward communication and skill-building-but, I think, it can also be characterized by curiosity and intrinsic purpose.

46 lbid., 258. 


\section{Bibliography}

Auslander, Philip, "The Performativity of Performance Documentation," PAJ 84 (2006): 1-10.

Bawden, David, and Lyn Robinsin, Introduction to Information Science (Chicago: NealSchuman, 2012).

Becker, Howard, Art Worlds (Berkeley: University of California Press, 1982).

Bénichou, Anne (Ed.), Ouvrir le document: Enjeux et pratiques de la documentation dans les arts visuals contemporains (Dijon, France: Les Presses du Réel, 2010).

Briet, Suzanne, What Is Documentation?, trans. Ronald E. Day, Laurent Martinet, and Hermina G. B. Anghelescu (Langham, MD: Scarecrow Press, 2006), 9-46.

Buckland, Michael K., "Document Theory: An Introduction," in Records, Archives and Memory: Selected Papers from the Conference and School on Records, Archives and Memory Studies, University of Zadar, Croatia, May 2013, ed. Mirna Willer, Anne J. Gilliland, and Marijana Tomić (Zadar, Croatia: University of Zadar, 2015), 223-239.

Buckland, Michael K., "Northern Light: Fresh Insights into Enduring Concerns," in A Document (Re)turn: Contributions from a Research Field in Transition, ed. Roswitha Skare, Niels Windfeld Lund, and Andreas Vårheim (Frankfurt, Germany: Peter Lang, 2007), 316-322.

Buckland, Michael K., "What is a 'Document'?," Journal of the American Society for Information Science 48, no. 9 (1997): 804-809.

Case, Donald O., and Lisa G. Given, Looking for Information: A Survey of Research on Information Seeking, Needs and Behavior (4th ed.) (Bingley, UK: Emerald, 2016).

Chandler, Daniel, Semiotics: The Basics (2nd ed.) (New York: Routledge, 2007).

Cowan, Sandra, "Informing Visual Poetry: Information Needs and Sources," Art Documentation 23, no. 2 (2004): 14-20.

Day, Ronald E., Indexing It All: The Subject in the Age of Documentation, Information, and Data (Cambridge, MA: The MIT Press, 2014).

Feinberg, Melanie, "Reading Databases: Slow Information Interactions Beyond the Retrieval Paradigm," Journal of Documentation 73, no. 2 (2017): 336-356.

Fleck, Ludwig, Genesis and Development of a Scientific Fact (Chicago: University of Chicago Press, 1979).

Frohmann, Bernd, Deflating Information: From Science Studies to Documentation (Toronto: University of Toronto Press, 2004).

Goodman, Nelson, Languages of Art (2nd ed.) (Indianapolis, IN: Hackett, 1976). 
Heidegger, Martin, "The Origin of the Work of Art," in Poetry, Language, Thought, trans. Albert Hofstadter (New York, NY: Harper \& Row, 1971), 15-86.

Hemmig, William S., "The Information-Seeking Behavior of Visual Artists: A Literature Review," Journal of Documentation 64, no. 3 (2008): 343-362.

Latham, Kiersten F., "Museum Object as Document," Journal of Documentation 68, no. 1 (2012): 45-71.

Krauss, Rosalind, "Notes on the Index: Seventies Art in America," October 3 (Spring 1977): 6881.

Latour, Bruno, and Steve Woolgar, Laboratory Life: The Social Construction of Scientific Facts (Princeton, NJ: Princeton University Press, 1986).

Lund, Niels Lund, "Document Theory." Annual Review of Information Science and Technology 43, no. 1 (2009): 399-432.

Lund, Niels Lund, "Documentation in a Complementary Perspective," in Aware and Responsible: Papers of the Nordic-International Colloquium on Social and Cultural Awareness and Responsibility in Library, Information and Documentation Studies (SCAR-LID), ed. W. Boyd Rayward (Lanham, MD: Scarecrow Press, 2004), 93-102.

Otlet, Paul, Traité de documentation: Le livre sur le livre: Théorie et pratique (Brussels: Editions Mundaneum, Palais Mondial, 1934).

Otlet, Paul, International Organisation and Communication of Knowledge: Selected Essays of Paul Otlet, trans. W. Boyd Rayward (Amsterdam: Elsevier, 1990).

Régimbeau, Gérard, "L'information et la documentation en art contemporain dans ses dispositifs: cadre théorique et études de cas," in Dispositifs info-communicationnels: Questions de médiations documentaires, ed. Viviane Couzinet (Paris: Lavoisier, 2009), 229-263.

Robinson, Lyn, "Information Science: Communication Chain and Domain Analysis," Journal of Documentation 65, no. 4 (2009): 578-591.

Skare, Roswitha, "Complementarity - A Concept for Document Analysis?," Journal of Documentation 65, no. 5 (2009): 834-840.

Skare, Roswitha, Niels Windfeld Lund, and Andreas Vårheim (Eds.), A Document (Re)turn: Contributions from a Research Field in Transition (Frankfurt: Peter Lang, 2007).

Tidline, Tonyia J., "Making Sense of Art as Information" (PhD diss., University of Illinois UrbanaChampaign, 2003).

Wilson, T. D., "Information Behavior: An Interdisciplinary Perspective," Information Processing and Management 33, no. 4 (1997): 551-572. 